\title{
Mindfulness and gamification in the higher education classroom: Friends or foes?
}

\section{Karadjova, Katia G.}

University Library, Humboldt State University, USA

\begin{abstract}
The paper provides short overview of the gamification, mindfulness and contemplative pedagogy approaches in higher education with focus on specific experiences in the Information Literacy (IL) field in higher education. Students seem to engage eagerly with both mindfulness activities and games in the classroom. Although at first these two might give an impression of activities which stand on opposite sides an evident overlapping has been present through employing games as mindfulness activities.

The paper discusses recent developments of the Brain Booth Initiative at a rural, public university as an example of an innovative practice, which shows how mindfulness and gamification complement each other in helping students optimize learning and support their wellbeing. In addition to the scholarly literature the Brain Booth initiative shows that librarians are well-positioned to adopt contemplative pedagogy in their information literacy instruction and to serve as resources for departmental faculty, who may be willing to explore its use in their courses.
\end{abstract}

Keywords: mindfulness; gamification; information literacy; contemplative pedagogy; undergraduate students; graduate students; academic library. 


\section{Introduction}

Mindfulness has been around for thousands of year within specific cultures over the world but only lately has started to make its way into the higher education classroom of the western world. Contemplative pedagogy has become recently a growing field of interest to some educators in colleges and universities. Gamification has also slowly but surely invaded the higher education classroom during the last decades. Recently, Information Literacy (IL) instruction practices have also experienced a noticeable infusion of both mindfulness approach in the classroom and gamification. Students seem to engage eagerly with both mindfulness activities and games in the classroom. Although at first these two might give an impression of activities which stand on opposite sides an evident overlapping has been present through employing games as mindfulness activities.

\section{Mindfulness and Gamification in the Information Literacy (IL) Field in Higher Education}

The section provides a short overview focusing on the most recent scholarly literature on mindfulness approaches, contemplative pedagogy and gamification in the IL field in higher education.

\subsection{Mindfulness and Contemplative Pedagogy}

Nowadays, college students face a lot of different challenges in a very fast-paced society. In general, they have to navigate between two major factors affecting their performance and wellbeing, namely, copying with stress (Coiro, Bettis \& Compas, 2017; Denovan \& Macaskill, 2013; Li \& Yang, 2016; Rose, Godfrey \& Rose, 2015; etc.) and dealing with distractions to sustain productive cognitive activities (Berry \& Westfall, 2015; Chen, 2015; Cheong, Shuter \& Suwinyattichaiporn, 2016; Lineweaver et al., 2012, etc.). As a result, lack of concentration known also as mind wandering is one of the pronounced problems among college students. Contemplative pedagogy offers educational methods that support the development of student attention, emotional balance, empathetic connection, compassion, and altruistic behavior, while also providing new pedagogical techniques that support creativity and the learning of course content (Zajonc, 2013).

Mindfulness is a mental state of focused attention in the present moment without judgmental perspectives. Scholars and practitioners have discussed in length mindfulness theories and practices (Hassed, 2015; Khazan, 2013; Langdonet al., 2011; McCown, Reibel \& Micozzi, 2016; Mckay, 2016; Paulson et al., 2013; Vago \& Silbersweig, 2012; etc.) with their perceived positive effects on the human wellbeing (Broderick, 2013; Brown \& Ryan, 2003; Cayoun, 2015; Kabat-Zinn, 2003; Rogers, 2012, etc.). 
The literature suggested that mindful practices could have a positive impact on student learning (Hartel, Nguyen \& Guzik, 2017; Hassed, 2015; Jennings, 2015; Rechtschaffen, 2016; Srinivasan, 2014), on reducing emotional exhaustion and improving workplace satisfaction and effectiveness (Hall, 2013; Hülsheger at al., 2013; Leroy, Dimitrova \& Sels, 2013), as well as on preventing mental health problems (Bettis et al., 2017; Brown \& Ryan, 2003; Cayoun, 2015).

Engagement with mindfulness practices and the use of contemplative classroom pedagogy supports such proven activities as intentional brain breaks, emotional self-regulation, and singular focus.

Intentional brain breaks: taking as little as a few minutes to give the brain a break from thinking, can lead to better focus and better academic study outcomes (Bamber \& KraenzleSchneider, 2016; Hassed, 2015).

Emotional self-regulation practice (Cayoun, 2015; Mckay, 2016): educators ask students to engage in courageous conversations both in- and outside of the classroom. Teaching contemplation and mindfulness is a way to prepare students to more successfully engage in those conversations while also teaching them to cultivate patience and compassion for diverse viewpoints (Kabat-Zinn, 2012; Shapiro et al., 2008). All these facilitate and complement applying critical pedagogy in the classroom.

Singular focus: many students struggle with attempting to multitask as well as foster strong, singular focus when it is needed for short or sustained periods of time. Mindfulness training has quite immediate impacts on attention and focus (Hassed, 2015; Moniz et al., 2015; Shapiro et al., 2008, etc.).

Some scholars and practitioners have gone even further by designing and conducting ongoing mindfulness training in the classroom across curriculum to support an attentive, present centered, and non-reactive mental mode (Hartel, Nguyen \& Guzik, 2017; Morrison et al., 2014) as well as by development and standardization of mindfulness qualities scale for college students (Arunya \& Thamilselvan, 2017).

Lately, librarians have started to pay attention to mindfulness and to engage with mindful practices (Mastel \& Innes, 2013; Moniz et al., 2015; Ruhlmann, 2017, etc.). A few university libraries have even started to dedicate time and spaces to mindfulness activities. Most of these libraries focus primarily on meditation. A recent study (Mourer \& Karadjova, 2017) was the first one to involve a broader spectrum of mindfulness activities, which offer intentional brain breaks to students, faculty and staff. The results reported on high interest for this innovative approach among students. Further analysis of patterns of use suggested preferences for certain mindfulness activities. This research study provided evidence to support educators' use of contemplative pedagogy and its value in the information literacy 
workplace. It also showed an overlapping of mindful practices and gamification through employing games as mindfulness activities.

\subsection{Gamification}

Gamification is defined in Merriam-Webster Dictionary as "the process of adding games or gamelike elements to something (such as a task) so as to encourage participation". There has been significant amount of experimentation in the realm of information literacy gamification (Clyde \& Thomas, 2008; Cowing, 2017; Kearns et al., 2017, Laubersheimer et al., 2016; Markey et al., 2011; Porter, 2012; Smale, 2011, etc.) that has led to some ideas about best practices. The typology of trivia, role-playing, casual, physical/virtual mix, alternate reality, and social is a good one and allows some comparative work to happen about the most effective kinds of game design in a library context (Broussard, 2012). For example, the use of an immersive first-person experience and a narrative similar to many commercial games seems that potentially could be a useful method to engage complex information literacy skills Clyde \& Thomas, 2008). The challenge with gamification seems to be creating the right level of fun and 'immersiveness' of virtual reality in a way that engages user expectations of what games are nowadays while still imparting meaningful skills.

Some publications on the gamification in the information literacy field focus on the theoretical aspects of gamification (Becker, 2013; Cheong et al., 2014; Felker, 2014), which includes both the creation of games but also the incorporation of game-like structures into instruction. The rethinking of how instruction works may entail the redesign of entire instruction programs as opposed to just the addition of a game to the toolkit of learning objects (Felker, 2014). There has been a fair amount of success in hybrid games that require in-person exploration in the library. When connected to an app or even some low-tech way of creating a quest framework, games seem to have been effective in getting patrons to explore a library and its resources. It has been most effective as part of an information literacy instruction session embedded in specific courses, where employing games as an active learning technique makes imparting the necessary information a more fun experience (Broussard, 2012; Margino, 2013).

\section{Students Engagement with Mindfulness and Games through the Brain Booth Initiative}

We have started the Brain Booth Initiative about two years ago. The Brain Booth has the goal of introducing mindfulness as a means of introducing students to metacognition for academic success. The Library Brain Booth is an informal, experiential space to learn about the mind body connection and optimize learning. 
Mission: The Library Brain Booth seeks to introduce the campus community to international scientific research on the effects of mindfulness, attention, and contemplation through hands-on tools and activities in an informal, experiential setting. Students are especially encouraged to explore the positive impacts that taking an intentional brain break can have on their academic success. Although the Library Brain Booth recognizes the contributions of people of all faiths and backgrounds to mindfulness practices, it has no religious affiliation. People of all abilities, cultures, and faiths are welcome in the Library Brain Booth.

The Brain Booth offers different activity stations: color-relax, game-relax, light-therapy, sound-relax, audio-meditate, prompt-meditate, video-meditate, gratitude-express, virtual reality-immerse, and biofeedback. The biofeedback unit is a resilience training device that measures your coherence levels and heart rate variability (HRV). Coherence directly impacts how you physiologically react to and reduce stress. The Brain Booth hosts weekly drop-in hours as well as provides equipment to check out at the library circulation desk and use at the Brain Booth Designated Open Space (BBDOS). The BBDOS also accommodates a book \& media collection on mindfulness and contemplative pedagogy, a stationary biofeedback machine, two pedal desks, and a meditation corner.

The initiative has been received very well by the campus community. During the last semester the Brain Booth was embedded in the course curricula across the departments of Child Development and Kinesiology \& Recreation Administration. The School of Business joined them this semester. The departments to follow next semester are World Languages \& Cultures and Psychology.

In relation to a course curriculum assignment students visited the Brain Booth during class time, engaged with the activities and had to write a reflection on the activities in relation to their studies and their wellbeing. Overall, the students acknowledged the high value of the approach. They expressed high interest in the game-relax station which was among the top three preferred activities along with color-relax and biofeedback.

\section{Conclusions}

In addition to the scholarly literature the Brain Booth initiative shows that librarians are well-positioned to adopt contemplative pedagogy in their information literacy instruction and to serve as resources for departmental faculty, who may be willing to explore its use in their courses. It also attests that mindfulness and gamification complement each other as suggested by the literature. As of now we are working on designing and developing an experimental study which connects directly mindfulness in the classroom with assessment of student learning outcomes. 


\section{References}

Arunya, B., \& Thamilselvan, P. (2017). Development and standardization of Mindfulness Qualities Scale for college students. Indian Journal Of Positive Psychology, 8(1), 64-67.

Bamber, M. D., \& Kraenzle Schneider, J. (2016). Mindfulness-based meditation to decrease stress and anxiety in college students: A narrative synthesis of the research. Educational Research Review, 18, 1-32. doi: 10.1016/j.edurev.2015.12.004

Becker, B. W. (2013). Gamification of library instruction. Behavioral \& Social Sciences Librarian, 32(3), 199-202. doi:10.1080/01639269.2013.821372

Berry, M. \& Westfall, A. (2015). Dial d for distraction: The making and breaking of cell phone policies in the college classroom. College Teaching, 63(2), 62-71.

Bettis, A. H., at al. (2017). Comparison of two approaches to prevention of mental health problems in college students: enhancing coping and executive function skills. Journal of American college health, 1-10.

Broderick, P. (2013). Learning to Breathe: A Mindfulness Curriculum for Adolescents to Cultivate Emotion Regulation, Attention, and Performance. Oakland, CA: New Harbinger Publications.

Broussard, M.J.S. (2012). Digital games in academic libraries: A review of games and suggested best practices. Reference Services Review, 40(1), 75-89. doi:10.1108/00907321211203649

Brown, K. W., \& Ryan, R. M. (2003). The benefits of being present: Mindfulness and its role in psychological well-being. Journal of Personality and Social Psychology: Interpersonal Relations and Group Processes, 84(4), 822-848. doi:http://dx.doi.org/10.1037/0022-3514.84.4.822

Cayoun, B. (2015). Mindfulness-integrated CBT for Well-being and Personal Growth: Four Steps to Enhance Inner Calm, Self-confidence and Relationships. Chichester, West Sussex: John Wiley \& Sons Inc.

Chen, V. (2015). From distraction to contribution: A preliminary study on how peers outside the group can contribute to students' learning. Canadian Journal for the Scholarship of Teaching and Learning, 6(3),

Cheong, C., Filippou, J., \& Cheong, F. (2014). Towards the gamification of learning: Investigating student perceptions of game elements. Journal of Information Systems Education, 25(3), 233-244.

Cheong, P., Shuter, R., \& Suwinyattichaiporn, T. (2016). Managing student digital distractions and hyperconnectivity: Communication strategies and challenges for professorial authority. Communication Education, 65(3), 272-289.

Clyde, J. \& Thomas, C. (2008) Building an information literacy first-person shooter. Reference Services Review, 36(4), 366-380. doi:10.1108/00907320810920342

Coiro, M. , Bettis, A. , \& Compas, B. (2017). College students coping with interpersonal stress: Examining a control-based model of coping. Journal of American College Health, 65(3), 177-186.

Cowing, J. (2017). Developing an online platform for gamified library instruction. Code4Lib Journal, 35. Retrieved from http://journal.code4lib.org/articles/12122 
Definition of gamification. Merriam-Webster Dictionary. Retreived on January 31, 2017 from https://www.merriam-webster.com/dictionary/gamification

Denovan, A., \& Macaskill, A. (2013). An interpretative phenomenological analysis of stress and coping in first year undergraduates. British Educational Research Journal, 39(6), 1002-1024. doi:10.1002/berj.3019

Felker, K. (2014). Gamification in libraries: The state of the art. Reference \& User Services Quarterly, 54(2), 19-23.

Hall, L. (2013). Mindful Coaching: How Mindfulness Can Transform Coaching Practice. London: Kogan Page Limited.

Hartel, J., Nguyen, A., \& Guzik, E. (2017). Mindfulness Meditation in the Classroom. Journal Of Education For Library \& Information Science, 58(2), 112-115.

Hassed, C. (2015). Mindful Learning : Reduce Stress and Improve Brain Performance for Effective Learning. Boston: Shambhala Publications.

Hülsheger, U. R., Alberts, H. J. E. M., Feinholdt, A., \& Lang, J. W. B. (2013). Benefits of mindfulness at work: The role of mindfulness in emotion regulation, emotional exhaustion, and job satisfaction. Journal of Applied Psychology, 98(2), 310-325. doi:http://dx.doi.org/10.1037/a0031313

Jennings, P. (2015). Mindfulness for Teachers: Simple Skills for Peace and Productivity in the Classroom. New York: W.W. Norton \& Company.

Kabat-Zinn, J. (2003). Mindfulness-based interventions in context: past, present, and future. Clinical psychology: Science and practice, 10(2), 144-156.

Kearns, A., Kirsch, B. A., \& Cononie, V. (2017). Agoge: An information literacy game for transfer students. Reference Services Review, 45(2), 314-331. doi:10.1108/RSR-092016-0054

Khazan, I. (2013). The Clinical Handbook of Biofeedback: A Step by Step Guide for Training and Practice with Mindfulness. Chichester, West Sussex, U.K.: WileyBlackwell.

Langdon, S., Jones, F. W., Hutton, J., \& Holttum, S. (2011). A grounded-theory study of mindfulness practice following mindfulness-based cognitive therapy. Mindfulness, 2(4), 270-281.

Laubersheimer, J., Ryan, D., \& Champaign, J. (2016). InfoSkills2Go: Using badges and gamification to teach information literacy skills and concepts to college-bound high school students. Journal of Library Administration, 56(8), 924-938. doi:10.1080/01930826.2015.1123588

Leroy, H., Anseel, F., Dimitrova, N. G., \& Sels, L. (2013). Mindfulness, authentic functioning, and work engagement: A growth modeling approach. Journal of Vocational Behavior, 82(3), 238-247.

Li, M., \& Yang, Y. (2016). A Cross-Cultural Study on a Resilience-Stress Path Model for College Students. Journal Of Counseling \& Development, 94(3), 319-332. doi: $10.1002 /$ jcad. 12088

Lineweaver, T., Kercood, S. , O'Keeffe, N. , O'Brien, K. , Massey, E. , et al. (2012). The effects of distraction and a brief intervention on auditory and visual-spatial working 
memory in college students with attention deficit hyperactivity disorder. Journal of Clinical \& Experimental Neuropsychology, 34(8), 791-805.

Margino, M. (2013). Revitalizing traditional information literacy instruction: Exploring games in academic libraries. Public Services Quarterly, 9, 333-341.

Markey, K., Leeder, C., \& Hofer, A. (2011). Bibliobouts: What's in a game? College \& Research Libraries News, 72(11), 632-645. Retrieved from http://crln.acrl.org/index.php/crlnews/article/view/8668/9124

Mastel, K., \& Innes, G. (2013). Insights and practical tips on practicing mindful librarianship to manage stress. LIBRES: Library and Information Science Research Electronic Journal, 23(1), 1-8.

Mckay, M. (2016). Emotion Efficacy Therapy: A Brief, Exposure-based Treatment for Emotion Regulation Integrating ACT and DBT. Oakland, CA: Context Press.

McCown, D., Reibel, D., \& Micozzi, M. (2016). Resources for Teaching Mindfulness: An International Handbook. Switzerland: Springer Verlag.

Morrison, A.B., Goolsarran, M., Rogers, S.L. \& Jha, A.P. (2014). Taming a wandering attention: short-form mindfulness training in student cohorts. Frontiers in Human Neuroscience, 7, DOI: 10.3389/fnhum.2013.00897

Moniz, R., Eshleman, J., Henry, J., Slutzky, H., \& Moniz, L. (2015). The Mindful Librarian: Connecting the Practice of Mindfulness to Librarianship. Chandos Publishing.

Mourer, M. M \& Karadjova, K.G. (2017). Dare to Share the Silence: Tools \& Practices of Contemplative Pedagogy in a Library Brain Booth, In S. Kurbanoglu et al. (Eds.) Information Literacy in the Workplace. ECIL 2017 Conference proceedings in Communications in Computer and Information Science. Heidelberg, Germany: Springer.

Paulson, S., Davidson, R., Jha, A., \& Kabat-Zinn, J. (2013). Becoming conscious: the science of mindfulness. Annals of the New York Academy of Sciences, 1303(1), 87-104.

Porter, T. D. (2012). Games and activities: An alternative foundation for library instructional learning. Codex: The Journal of the Louisiana Chapter of the ACRL, 2(2), 61-77.

Rechtschaffen, D. (2016). The Mindful Education Workbook: Lessons for Teaching Mindfulness to Students. New York: W.W. Norton \& Company.

Rogers, H. (2012). Mindfulness for the Next Generation: Helping Emerging Adults Manage Stress and Lead Healthier Lives. New York, New York: Oxford University Press.

Rose, C., Godfrey, K., \& Rose, K. (2015). Supporting student wellness: De-stressing initiatives at memorial university libraries. Partnership: The Canadian Journal of Library and Information Practice and Research, 10(2), 1-21.

Ruhlmann, E. (2017). Mindful librarianship. American Libraries, 48(6), 44-47.

Shapiro, S. L., Brown, K. W., \& Astin, J. A. (2008). Toward the integration of meditation into higher education: A review of research. The Center for Contemplative Mind in Society. Retrieved from http://www. contemplativemind. org/admin/wpcontent/uploads/2012/09/MedandHigherEd.pdf. 
Smale, M. A. (2011). Learning through quests and contests: Games in information literacy instruction. Journal of Library Innovation, 2(2), 36-55.

Srinivasan, M. (2014). Teach, Breathe, Learn: Mindfulness in and out of the Classroom. Berkeley, California: Parallax Press.

Vago, D. R., \& Silbersweig, D. A. (2012). Self-awareness, self-regulation, and selftranscendence (S-ART): a framework for understanding the neurobiological mechanisms of mindfulness. Frontiers in human neuroscience, 6 .

Vanden Elzen, A. M. \& Roush, J. (2013). Brawling in the library: Gaming programs for impactful outreach and instruction at an academic library. Library Trends, 61(4), 802813.

Zajonc, A. (2013). Contemplative pedagogy: a quiet revolution in higher education. New Directions for Teaching and Learning, 2013(134), 83-94. 